\title{
Determination of Nursing Practices Related to Drain Care
}

\section{Dren Bakımına İlişkin Hemşirelik Uygulamalarının Belirlenmesi}

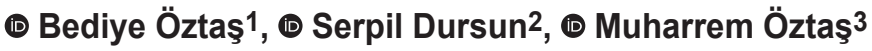 \\ ${ }^{1}$ Ankara Medipol University, Nursing, Ankara, Turkey \\ ${ }^{2}$ Gülhane Training and Reserach Hospital, Nursing, Ankara, Turkey \\ ${ }^{3}$ Gülhane Training and Reserach Hospital, Clinic of General Surgery, Ankara, Turkey
}

\section{HIIIIII| ABSTRACT}

Aim: Drains are frequently used for both therapeutic and prophylactic purposes during surgical procedures. Nurses have important duties in the process from insertion to removal of drain. The aim of this study was to determine the nursing practices related to drain care and to determine the problems experienced by nurses related to drain care.

Method: The study was conducted as descriptive and cross-sectional. The sample of the study consisted of 120 nurses working in surgical clinics who accepted to participate in the study. The data collection form, which was created by the researchers by searching the literature, was used in the data collection. The purpose of the study was explained to the participants and their verbal and written informed consents were obtained. The nurses were asked to complete the data collection form by using face to face interview method. Statistical Package for Social Sciences version 21.0 for Windows was used in the analysis of the data collected within the scope of the study. Statistical data were expressed as mean \pm standard deviation and percentage (\%).

Results: Of the nurses participated in the study, $98.3 \%$ were woman. The mean age of nurses was $35.90 \pm 6.38,65 \%$ of them were married, $71.7 \%$ were undergraduates, and 38.3\% had worked for 11-20 years. All of the nurses stated that they performed active and passive drain monitoring. The nurses stated that they performed drain monitoring at a frequency ranging from 10 minutes to 24 hours. The most difficult situation for the nurses was that the patients and their relatives and other healthcare personnel emptied the drains without recording. The nurses stated that the most undesirable situation in drain care was the displacement of the drain. In order to ensure the safety of the drain, $41.6 \%$ ( $n=50$ ) of the nurses gave education to the patients and $23.3 \%$ stated that they performed appropriate fixation applications. Nurses are actively involved in drain care and encounter many problems in performing their duties.

Conclusion: Finding solutions to problems will positively affect the quality of nursing care and patient outcomes.

Keywords: Drainage, nursing care, monitoring

\section{|||||||||| ÖZ}

Amaç: Drenler cerrahi işlemler sırasında sıklıkla hem tedavi edici hem de profilaktik amaçla kullanılmaktadır. Drenin takılmasından çıkarılmasına kadar geçen süreçte hemşirelere önemli görevler düşmektedir. Bu çalışmanın amacı; dren bakımına ilişkin yapılan hemşirelik uygulamalarının belirlenmesine ek olarak dren bakımı ile ilgili hemşirelerin yaşadıkları problemleri de belirlemektir.

Yöntem: Araştırma tanımlayıcı ve kesitsel olarak yürütülmüştür. Araştırmanın örneklemini cerrahi kliniklerde çalışan ve araştırmaya katılmayı kabul eden 120 hemşire oluşturmuştur. Verilerin toplanmasında araştırmacılar tarafından literatür taraması yapılarak oluşturulmuş veri toplama formu kullanılmıştır. Katılımcılara araştırmanın amacı açıklanmıştır ve katılımcıların sözlü ve yazılı onamları alınmıştır. Hemşirelerle yüz yüze görüşme yöntemi kullanılmıştır ve hemşirelerden veri toplama formunu doldurmaları istenmiştir. Çalışma kapsamında toplanılan verilerin analizinde, Statistical Package for Social Sciences, Windows için sürüm 21.0 bilgisayar paket programı kullanılmıştır. İstatistiksel veriler ortalama \pm standart sapma ve yüzde (\%) olarak ifade edilmiştir.

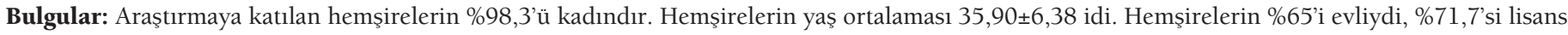
mezunuydu ve \%38,3’ü 11-20 yıl arası çalışma yılına sahipti. Hemşirelerin tamamı aktif ve pasif dren takibi yaptıklarını ifade etmişlerdir. Hemşireler 10 dakika ile 24 saat aralığında değissen sıklıkta dren takibi yaptıklarını ifade etmişlerdir. Hemşirelerin en fazla zorluk çektiği durum hasta ve yakınları

Address for Correspondence/Yazışma Adresi: Bediye Öztaş,

Ankara Medipol University, Nursing, Ankara, Turkey

E-mail: oztasbediye2@gmail.com ORCID ID: orcid.org/0000-0001-6775-1405

Received/Gelis Tarihi: 26.11.2019 Accepted/Kabul Tarihi: 10.01.2020

${ }^{\circ}$ Copyright 2020 by Turkish Society of Colon and Rectal Surgery

Turkish Journal of Colorectal Disease published by Galenos Publishing House. 
ile diğer sağlık elemanlarının drenleri kayıtsız olarak boşaltmasıdır. Hemşireler dren bakımında en fazla gerçekleşen istenmeyen durumun drenin yerinden çıkması olduğunu belirtmişlerdir. Dren güvenliğini sağlamak için hemşirelerin \%41,6'sı (n=50) hastalara eğitim verdiğini, \%23,3'ü ise uygun sabitleme uygulamalarını yaptıklarını ifade etmişlerdir. Hemşireler dren bakımında aktif olarak görev almakta ve görevlerini yerine getirirken de birçok problemle karşılaşmaktadır.

Sonuç: Problemlere yönelik çözümlerin bulunması hemşirelik bakım kalitesini ve hasta çıtılarını olumlu etkileyecektir.

Anahtar Kelimeler: Drenaj, hemşirelik bakımı, takip

\section{Introduction}

Surgical wound drainage is an integral part of modern surgical practices used to evacuate air and fluid that are likely to collect in the wound bed in the postoperative period. ${ }^{1}$ Surgical procedures create dead spaces in the areas where they are applied. The body tends to fill these spaces with air or fluid. The drains used for the discharge of air or fluid accumulating in these spaces can generally be grouped into two groups: Active drains use negative pressure to drain the collection that has accumulated in a wound site. Examples include hemovac drains and chest drainage tubes. Passive drains provided the movement of the liquid or air inside the wound from the high pressure area to the region where the pressure is lower, by making use of the pressure difference between the inside and outside of the wound. Penrose drains and nasogastric tubes are examples of these drains. ${ }^{2,3}$ The purposes of use of drainage catheters are to decrease the infection rates by preventing accumulation of fluid or air, to prevent seroma accumulation in the surgical area, to identify and evaluate anastomosis leaks, and to provide abscess drainage that can also be performed percutaneously for therapeutic purposes. There are studies showing that the use of drains reduces the rate of infection. ${ }^{4,8}$ In contrast, there are also studies that do not recommend the routine use of drainage catheters because they increase the risk of retrograde infection. ${ }^{9,10}$ The generally accepted view when drain is used in patients undergoing surgery is carefully monitoring the amount of drainage to determine the most appropriate time for removing the drainage tubes. ${ }^{1,11}$ This situation may affect the length of hospital stay, postoperative clinical status, health care cost and infection formation. ${ }^{1}$

A wide range of drainage systems are used in surgical clinics such as hemovac drain, chest drainage tube, nasogastric tube, penrose drain and lumbar drain. Drains used in this wide range can also have complications. These can be breaking, difficulty in removing, unwanted removal, infection, occlusion, pain, ugly scar and visceral perforation. Breaking is a rare complication that can develop due to the quality of the material used. Difficulty in removing is a complication that additional surgery may be required to remove the drain due to adhesion during the healing process of the tissue in the entrance area as a result of the long drain placed. Unwanted removal may be caused by the healthcare personnel by removing the wrong drain or by the patient or it can remove spontaneously. ${ }^{12}$ Although one of the purposes of placing the drains is to prevent infection, retrograde infections may develop as the length of stay of the drain increases. ${ }^{2}$ Drain tubes may become occluded due to tissue, blood clots, or mechanical compression. This can increase the risk of infection by preparing the ground for hematoma formation. Although pain varies depending on the location of the drain and the patient, it can reach levels that may affect patients at a serious level, from mild to inhibition of mobilization. Ugly scar is a cosmetically bad scar tissue formation, especially when the drain needs to stay for a long time. Drains placed for a long time can cause rupture of the internal organs and membranes (Visceral perforation). In light of all this information, it is seen that nurses working in surgical clinics have important duties in drain care. Careful follow-up of the drain in terms of color, odor and quantity, follow-up in terms of signs of infection, performing evidence-based practices to prevent infection, follow-up of the drain in terms of complications, taking measures to prevent unwanted events, training of patients and their relatives are among the duties of the nurse. Drain care constitutes a small but important part of the health care offered by surgical nurses. ${ }^{13,14}$ In the literature, no study evaluating the practices of nurses on drain care has been found. Therefore, with this study, it is planned to discuss with the evidence based information about drain care and to determine the practices of nurses about drain care in the current system and the problems they experience while doing drain care and to guide nursing practices in drain care, which is an important part of nursing care.

\section{Materials and Methods}

The research was carried out descriptively and crosssectionally in order to determine the practices and problems experienced by nurses about drain care. The research was conducted between 01-31 May 2019 with nurses who worked in the General Surgery, Cardiovascular Surgery, Urology, Orthopedics and Traumatology, Plastic and Reconstructive Surgery and Thoracic Surgery clinics in a Training and Research Hospital in Ankara, and volunteered to participate in the study. The universe of the study consisted of 141 nurses working in surgical clinics. No 
sample selection was made in the study, and 120 nurses who met the study inclusion criteria and agreed to participate in the study constituted the sample of the study. In the study, $85.1 \%$ of the nurses were reached. Inclusion criteria were; working as a nurse in surgical clinics, knowing Turkish, being 18 years old or older, accepting to participate in the research. Exclusion criteria were; not having the criteria of being included in the research and refusing to participate in the research at any stage. The ethical committee (Ethics Committee Project/Decision No: 19/164, xxxxx 2019) and institutional approvals were taken to conduct the research. Written and verbal consents of those who volunteered to participate in the study were obtained by informing the participants about the research. The data collection form was developed by the researchers by making use of the

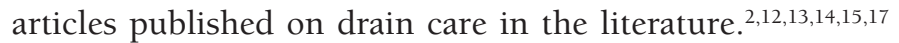
Opinions of 2 medical doctors who had expertise in the field of surgery and 2 nurses working as faculty members in the department of surgical diseases nursing were taken while preparing the questions. To test the clarity of the questions, pre-application was made with 10 nurses. Nurses were asked to fill in the data collection form using face-toface interview technique. Nurses answered all the questions in the data collection form by writing. The data collection form consisted of a total of 16 questions to determine the identifying data of nurses (such as age, gender, educational status) and nursing practices performed in the care of patients with drains.

\section{Statistical Analysis}

Statistical Package for Social Sciences (SPSS), version 21.0 for Windows was used in the statistical analysis of the data obtained. Descriptive statistics were used in the analysis of the data collected as mean \pm standard deviation $(X \pm S D)$ and median or percentage (\%). The answers given to the openended questions were recorded by writing tally in Microsoft Word. The answers were read twice independently by the researchers. Expressions that pointed to the same subject were combined. Then, the researchers came together and categorized the statements. Statements categorized were corrected by consulting the health professionals who were asked for preparing the questions. The results obtained from the study were reviewed with 10 nurses included in the study and it was evaluated whether the categorized statements overlapped with what they said.

\section{Results}

The sociodemographic characteristics of the participants are given in Table 1. Of the nurses participating in the research, $98.3 \%$ were women. The average age of nurses was $35.90 \pm 6.38,65 \%$ were married, $71.7 \%$ were undergraduate, $38.3 \%$ had a working year of 11-20 years.
All of the nurses stated that they followed up active and passive drains. The nurses stated that they followed up drains at 10 to 30 minutes and at $1,2,4,12$ to 24 hours intervals. Problems and complications faced by nurses in drain care are given in Table 2 . The problem that nurses faced most was emptying the drain without recording by the patient, relatives and other health personnel $(64.9 \%, \mathrm{n}=78)$. The applications of nurses regarding drain care are given in Table 3. It was determined that the nurses carried out applications such as training of patients and fixing the drain in order to ensure drain safety. The nurses stated that they carried out applications such as draining the drain entrance site, paying attention to aseptic conditions, applying antibiotic treatment according to the request and following up the drain entrance site in terms of signs of infection to prevent drain related infections.

Nursing practices for the continuation of negative pressure were; attaching the cover after emptying the drain and emptying the air inside the drain $(13.3 \%, \mathrm{n}=16)$, draining when the drain is filled ( $5 \%, \mathrm{n}=6)$, informing the patient about that $(13.3 \%, \mathrm{n}=16)$, and milking and controlling the

Table 1. Characteristics of the nurses $(n=120)$

\begin{tabular}{|c|c|c|}
\hline Characteristics & $\mathbf{n}$ & $\%$ \\
\hline \multicolumn{3}{|l|}{ Gender } \\
\hline Female & 118 & 98.3 \\
\hline Male & 2 & 1.7 \\
\hline \multicolumn{3}{|l|}{ Marital status } \\
\hline Married & 78 & 65 \\
\hline Single & 42 & 35 \\
\hline \multicolumn{3}{|l|}{ Education status } \\
\hline High school & 2 & 1.7 \\
\hline Undergraduate & 4 & 3.3 \\
\hline Graduate & 86 & 71.7 \\
\hline Postgradute & 24 & 20 \\
\hline Doctorate & 4 & 3.3 \\
\hline \multicolumn{3}{|l|}{ Occupation years } \\
\hline $0-1$ & 6 & 5 \\
\hline $2-5$ & 12 & 10 \\
\hline $6-10$ & 28 & 23.3 \\
\hline $11-20$ & 46 & 38.3 \\
\hline 21 years or over & 28 & 23.3 \\
\hline \multicolumn{3}{|l|}{ Unit Worked } \\
\hline General Surgery & 45 & 37.5 \\
\hline Orthopedics & 15 & 12.5 \\
\hline Plastic Surgery & 10 & 8.3 \\
\hline Chest Surgery & 7 & 5.8 \\
\hline Urology & 12 & 10 \\
\hline Cardiovascular Surgery & 31 & 25.8 \\
\hline Mean age $35.90 \pm 6.38$ & Total $=120$ & Total $=100$ \\
\hline
\end{tabular}


drain $(21.6 \%, \mathrm{n}=26)$. Of the nurses, $75 \%(\mathrm{n}=90)$ answered "yes" to the question "Are you doing milking?" and 25\% $(\mathrm{n}=30)$ answered "no". All the nurses stated that they decided based on the amount and color of the drain content for the question of "How is the drain removal time determined ?".

\section{Discussion}

Although it is not necessary to use it in some surgical procedures, drain use is an integral part of modern surgical applications in patients undergoing surgery. Nurses providing patient care services in surgical clinics have important duties related to drain care. In our study, it was observed that the nurses followed up the drain with a frequency ranging from 10 minutes to 24 hours. Knowing the patient's surgical history can provide information about how often the drain should be followed up. According to the location of the drain and the bleeding risk of the patient, the medical team's frequent follow-up of the patients will allow

Table 2. Problems and complications faced by nurses in drain care

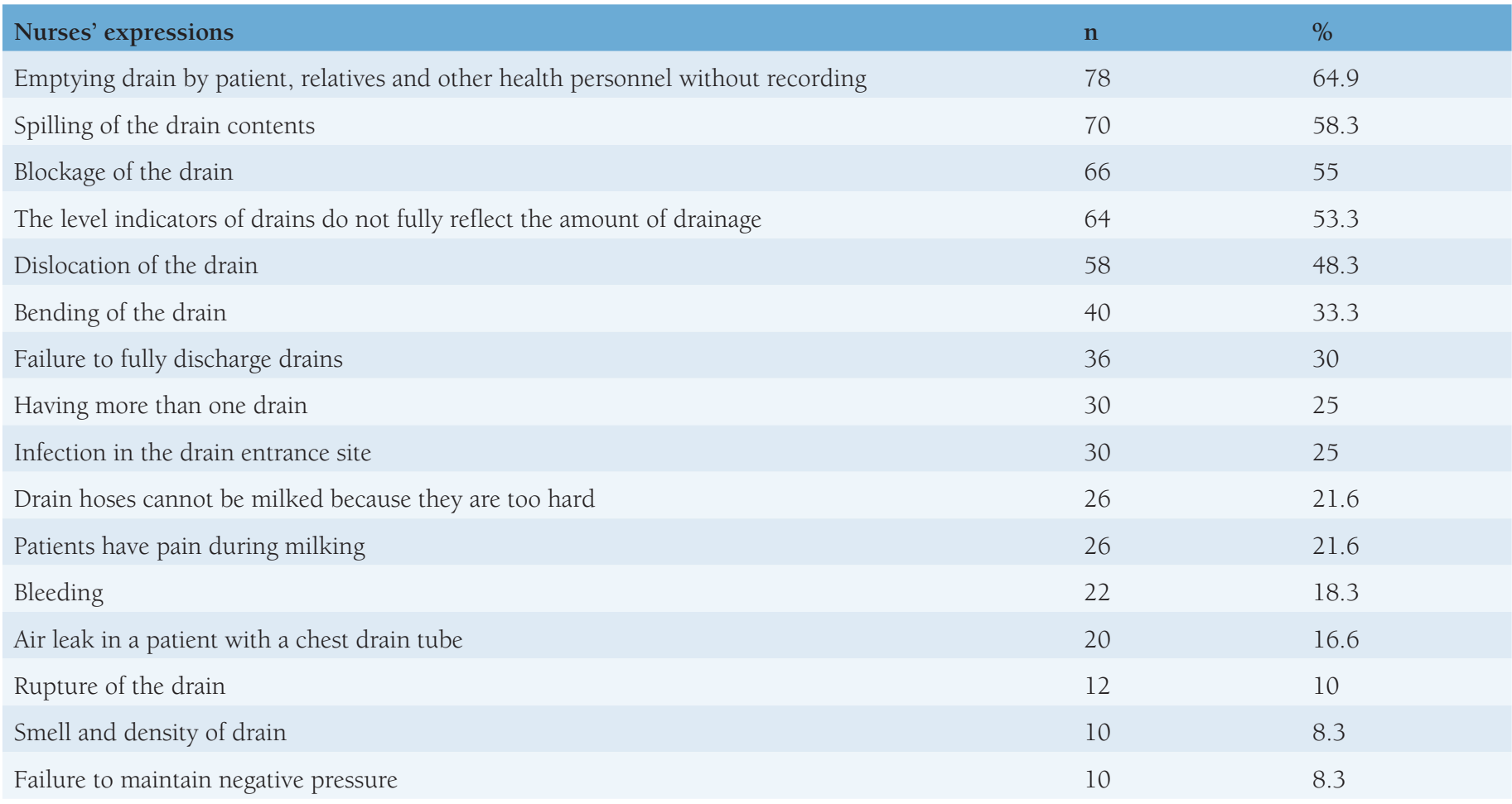

Table 3. Practices of nurses on drain care

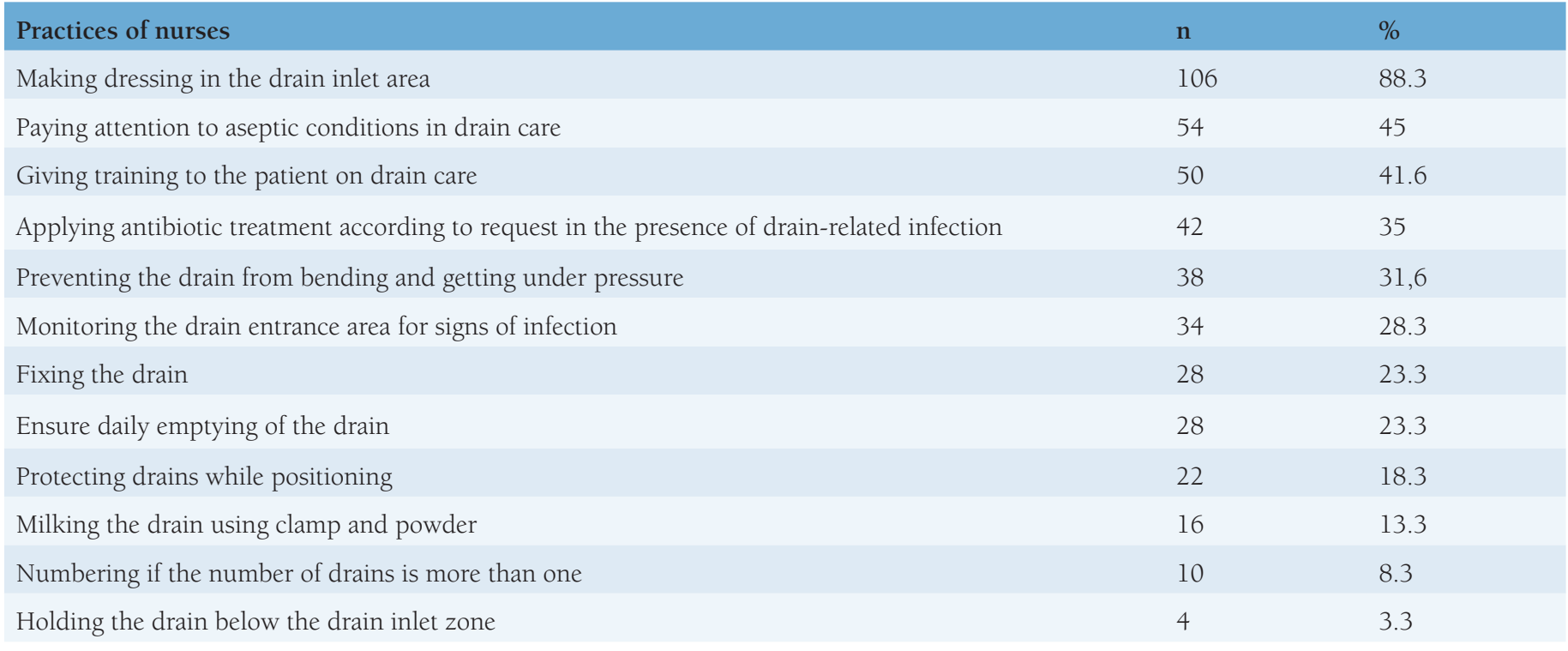


the complications that may develop to be detected early and intervene. ${ }^{15}$

Simple or large surgical procedures are performed in a very wide population ranging from newborn patients to elderly patients with conscious sedation or general anesthesia. In the vast majority of these operations, the use of drains is inevitable. In our study, it was seen that nurses performed many applications to ensure drain safety. In our study, nurses stated that they performed patient training and fixing the drain practices for drain care among the applications related to the subject. In the study by Yllmaz et al. ${ }^{12}$, the reasons for the displacement of the drain were as follows: Of the patients, $66.67 \%$ removed the drain by themselves; in $16.67 \%$ of them, the drain was removed spontaneously or the wrong drain was removed during follow-up. In our study, $8.9 \%$ of the nurses $(n=10)$ stated that they enumerated when there was more than one drain. With this application, drains were not mixed. In order to ensure drain safety in this large population, nurses should include the drain safety in the nursing care plan by considering the patient's medical history in detail. In addition to the training of patients and their relatives, it is important to be careful about health personnel, especially during patient transfer, to prevent unwanted removal of the drain. It is important for nurses to provide training for assistant health personnel to ensure drain safety in order to prevent unwanted events. One of the applications that cause unwanted removal of the drain is the milking the drain process performed by the healthcare personnel. ${ }^{2}$ In our study, $75 \%$ of the nurses stated that they performed milking. Of the nurses, 13.3\% $(n=16)$ stated that they performed milking by using clamp and powder. Although it is preferred by most surgeons in clinical practice to prevent clogging of the drain, it requires attention because it can negatively affect the tissue healing process due to its high negative pressure, causing bleeding and tissue trauma. ${ }^{2}$ Nurses are advised to do milking whenever it is suspected of occlusion and to perform the procedure by limiting it as much as possible. If this application is to be done, it is recommended to carefully hold the drain close to the entrance to the patient with one hand, and to perform the milking process with an alcohol gauze to increase the slipperiness with the other hand. ${ }^{2}$

Another issue that can be considered within the scope of drain safety is to ensure the continuity of the negative pressure of the drain for active drains. In our study, a low number of nurses stated that to ensure the continuity of the negative pressure of the drain they carried out the practices of draining the air inside the drain and then attaching the cover and draining the drain as long as it filled. In addition to the effective functioning of the drain, it is necessary to ensure the continuity of the negative pressure of the drain to prevent surgical site infections. ${ }^{2}$ When Carruthers et al. ${ }^{16}$ compared the pulling force applied by the Jackson-Pratt drain with $100 \mathrm{~mL}$ reservoir with the pulling force applied by the Jackson-Pratt drain with $400 \mathrm{ml}$ reservoir, they found that the small reservoir was more successful. In the same study, when negative pressure was created by pressing from the side, it was determined that it was more effective than that created by pressing from the top and bottom. ${ }^{16}$ Khansa et al. ${ }^{17}$ found similar results in their study. In clinical practice, while the surgeon decides on the size and type of the drain, the use of research results in practicing drain care by nurses and other health professionals may shorten the duration of drain by ensuring effective drainage. Therefore, this situation may affect patient outcomes positively.

One of the main purposes of inserting a drain is to prevent infection that may develop depending on the collection after surgery. To prevent infections related to the drain, in addition to standard measures (hand hygiene, using gloves), using prophylactic antibiotics, evaluation of the drain (type of the drain, location of the drain, color, odor, density, evaluation of the skin around the drain), selection of drain closure (drain selection of dressing material for the drain closure according to the amount of exudate), washing with $3-5 \mathrm{cc} 0.9 \% \mathrm{NaCl}$ to ensure the continuity of the drain opening, milking the drain tube when it is suspected it is clogged, preventing the bending of the catheter, and following the content carefully and correctly to remove the drain when it is not necessary are required. The accepted general opinion is to remove the drain when drainage falls below $25 \mathrm{cc}$ per day. ${ }^{2,15}$ In our study, nurses stated that they performed many applications mentioned in the literature to prevent the development of infection related to the drain. All of the nurses stated that the time of drain removal was decided according to the content and color of the drain. In clinical practice, it is important that nurses follow the drain content accurately and carefully. An important detail that nurses have difficulty in drain care is that the patient, relatives and other healthcare personnel empty the drain content without recording. For any reason, errors in the records related to the drain follow-up may lead to premature or delayed removal of drain, which may adversely affect patient outcomes. According to the undesired situations detected in our study: The entire healthcare team including the patient and their relatives should behave sensitive about the subject. Communication should be kept without any problems about the drain content. Every patient with drain and their relatives should be trained about drain care and the nurses should follow up the drain carefully.

\section{Conclusion}

In conclusion, it could be said that the practices of nurses regarding drain care in our study were in parallel with 
the practices reported in the literature, but our rates of administration were lower. It is considered that inclusion of drain care in in-service training programs and planning of attempts to solve problems encountered in care in order to increase the use of evidence-based practices of nurses related to drain care will increase the quality of nursing care services and contribute positively to patient outcomes.

\section{Ethics}

Ethics Committee Approval: The ethical committee (Ethics Committee Project/Decision No: 19/164, 30.04.2019).

Informed Consent: Written informed consents were obtained.

Peer-review: Externally peer reviewed.

\section{Authorship Contributions}

Concept: B.Ö., M.Ö., Design: B.Ö., M.Ö., Data Collection or Processing: S.D., Analysis or Interpretation: B.Ö., M.Ö., Literature Search: B.Ö., M.Ö., S.D., Writing: B.Ö., M.Ö., S.D.

Conflict of Interest: No conflict of interest was declared by the authors.

Financial Disclosure: The authors declared that this study received no financial support.

\section{References}

1. Yue B, Nizzero D, Zhang C, Zyl NV, Ting J. Accuracy of surgical wound drainage measurements: an analysis and comparison. ANZ J Surg 2015;85:327-329.

2. Orth K. Preventing surgical site infections related to abdominal drains in the intensive care unit. Critical Care Nurse 2018;38:20-26.

3. Bulut A, Afşar T, Vatansever N. Hemşirelik ögrencilerinin cerrahi dren takibi ve bakımına yönelik bilgi düzeyleri. Adıyaman Üni. Sağlık Bilimleri Derg 2019;5:1278-1292.

4. Pan HD, Wang L, Peng YF, Li M, Yao YF, Zhao J, et al. Subcutaneous vacuum drains reduce surgical site infection after primary closure of defunctioning ileostomy. Int J Colorectal Dis 2015;30:977-982.
5. Nordmeyer M, Pauser J, Biber R, Jantsch J, Lehrl S, Kopschina C, Rapke C, Bail HJ, ForstR, Brem MH. Negative pressure wound therapy for seroma prevention and surgical incision treatment in spinal fracture care. Int Wound J 2016;13:1176-1179.

6. McMillan MT, Malleo G, Bassi C, Allegrini V, Casetti L, Drebin JA, et al. Multicenter, prospective trial of selective drain management for pancreatoduodenectomy using risk stratification. Annals of Surgery 2017;265:1209-1218.

7. Gausden EB, Sama AA, Taher F, Pumberger M, Cammisa FP, Hughes AP. Long-term sequelae of patients with retained drains in spine surgery. J Spinal Disord Tech 2015;28:37-39.

8. Kim SI, Lim MC, Bae HS, Shin SR, Seo SS, Kang S, et al. Benefit of negative pressure drain within surgical wound after cytoreductive surgery for ovarian cancer. Int J Gynecol Cancer 2015;25:145-151.

9. Tian J, Li L, Liu P, Wang X. Comparison of drain versus no-drain thyroidectomy: a meta-analysis. Eur Arch Otorhinolaryngol 2017;274:567577.

10. Kosins AM, Scholz T, Cetinkaya M, Evans G. Evidence-based value of subcutaneous surgical wound drainage: the largest systematic review and meta-analysis. Plastic and Reconstructive Surgery 2013;132:443-450.

11. Aykan A, Güzey S, Sahin İ, Oysul FG, Öztürk S, Akın A. Drains and drainage capabilities: quantitative analysis of drain efficiencies. Turk J Plast Surg 2016;24:1-7.

12. Yılmaz KB, Akıncı M, Şeker D, Güller M, Güneri G, Kulaçoğlu H. Cerrahi hastalarda dren ve kateter güvenliğini etkileyen faktörler. Ulusal Cer Derg 2014;30:90-92

13. Knowlton MC. Nurse's guide to surgical drain removal. Nursing Issue 2015;45:59-61.

14. Walker J. Patient preparation for safe removal of surgical drains. Nursing Standard 2007;21:39-41.

15. Durai R, Philip CH. Surgical vacuum drains: types, uses, and complications. AORN Journal 2010;91:266-274.

16. Carruthers KH, Eisemann BS, Lamp S, Kocak E. Optimizing the closed suction surgical drainage system. Plastic Surgical Nursing 2013;33:38-42.

17. Khansa I, Khansa L, Meyerson J, Janis JE. Optimal use of surgical drains: evidence-based strategies. Plastic and Reconstructive Surgery 2018;141:1542-1549 